\title{
䊦
}

\section{Pastorale elemente in Hebreërs}

\author{
C.J.H. Venter \\ Skool vir Kerkwetenskappe \\ Potchefstroomkampus \\ Noordwes-Universiteit \\ POTCHEFSTROOM \\ E-pos: casmar@lantic.net
}

\begin{abstract}
Pastoral elements in Hebrews

In this article the letter to the Hebrews is scrutinised in order to investigate possible elements that can be applied in pastoral care and ministering. After indicating certain expressions used for different nuances of proclaiming in Hebrews, the expression "parakalein" as central concept for pastoral care will be focused on. The spectrum of the ensuing research includes aspects like the great High Priest's purification of sin as foundation for pastoral care, and sympathy and empathy in the work of the great High Priest. Furthermore, viewpoints on the following are given: a pastoral relationship, the Hebrew term, "therapon", as specific expression for a caring minister; the instruction to the members of the congregation to be pastors for one another; spirituality, and possible indications of the meaning of suffering. Finally the pastoral elements of faith, hope and perseverance are discussed. In conclusion a summary of the most important pastoral elemens is given.
\end{abstract}

\section{Opsomming}

\section{Pastorale elemente in Hebreërs}

In hierdie artikel word die brief aan die Hebreërs nagegaan om moontlike elemente te verken wat in pastorale sorg en bediening toegepas kan word. Nadat sekere begrippe verken is wat vir verskeie verkondigingsnuanses in Hebreërs gebruik word, word gefokus op die begrip "parakalein" in Hebreërs as 'n sentrale aanduiding vir pastorale bediening. Die spektrum van die daaropvolgende ondersoek sluit aspekte soos die volgende in: die reiniging van sonde deur die groot Hoëpriester as fundering vir pastorale sorg en medelye en empatie in die werk van die groot Hoëpriester. Verder word gesigspunte gebied op 
pastorale verhouding, die begrip "therapon" in Hebreërs as spesifieke begrip vir dienaar, die opdrag aan gelowiges om herders vir mekaar te wees, spiritualiteit en die moontlike singewing van menslike lyding. Laastens word die pastorale aspekte van geloof, hoop en volharding bespreek en die artikel word afgesluit met 'n samevatting van die pastorale kernelemente in Hebreërs.

Hierdie artikel word opgedra aan professor Ben de Klerk, 'n gewaardeerde kollega en vriend in die Fakulteit Teologie aan die Noordwes-Universiteit. Hy het hom as vakman verdiep in die verskillende vakke in Praktiese Teologie, en in besonder in die vak Liturgiek. Ek dra juis hierdie artikel aan hom op, want hy het 'n pastorale hart vir die kudde van die groot Herder, en hy ervaar ook self die sorg van die Goeie Herder.

\section{Inleiding}

In die wyer veld van ondersoek in Praktiese Teologie word die aksent op verskeie temas geplaas. In wetenskaplike navorsing in die veld van die Homiletiek die afgelope jare word die aksent byvoorbeeld onder andere geplaas op die prediker as toeruster van die gemeente in 'n nuwe tyd (vgl. Pieterse, 2001:28). In aansluiting hierby word in verdere navorsing gewys op prediking in 'n tyd van transformasie (Brits, 2001; Johnston, 2001; Kruger, 2004). Ook die plek van die hoorder in die prediking word nader betrek in studiewerk, byvoorbeeld die gesindheid van die hoorder in die luisterproses (Kruger \& Venter, 2003; Du Preez \& Venter, 2007). Sedert die wending van die eeu met die verskyning van die werk van Pieterse, Prediking in 'n tyd van armoede (2001), kom pastorale aspekte nader in die visier. Ook Jang (2007) verwys in onderafdelings van sy studie oor kommunikatiewe prediking na pastorale elemente in Hebreërs.

Nie net in homiletiese navorsing nie, maar ook op 'n wyer vlak, word Hebreërs die afgelope tyd betrek as ontginningsbron vir 'n verskeidenheid temas in die teologie (Venter, 2001:513-536; Pfitzner, 1993:3; Kruger \& Venter, 2002b:573-592). Ondersoeke van Hebreërs vanuit die Nuwe-Testamentiese vakgebied fokus veral op aspekte soos vreemdelingskap en vaderland in Hebreërs (Opperman, 1995:26), terwyl Pfitzner (1993) die retorika in Hebreërs ondersoek. Die vraag of Hebreërs as preek beskou kan word, word ook deur verskeie outeurs aangeraak. Oor 'n wye front is daar wel eenstemmigheid dat Hebreërs beskou kan word as 'n preek met 'n briefslot 
(DeSilva, 2002:8-12; Opperman, 1995:26; Ellingworth, 1993:61; Guthrie, 1996:20-22).

Die doel van hierdie artikel is egter om spesifiek pastorale elemente - en nie in die eerste instansie hermeneutiese en homiletiese elemente nie - te ondersoek, te ontgin en te formuleer met die oog op verdere basisteoretiese navorsing in die pastorale wetenskap. Aan die einde van die artikel word enkele terreine aangestip waarop die ontginde elemente in herderlike bediening toegepas kan word.

Met die kwalifiserende woord pastoraal word vir die doeleindes van hierdie artikel die volgende verstaan: aspekte en elemente in Hebreërs wat aangewend kan word in herderlike bediening en versorging. In hierdie opsig bied Hebreërs byvoorbeeld inligting oor die nadere fundering van pastorale sorg in die Hoëpriesterskap van Christus, simpatie, medelye, verhouding, volharding, en die sin van lyding. Die wyse waarop hierdie elemente in gesprek en verkondiging betrek word, verg 'n afsonderlike studie en is nie die fokus van hierdie artikel nie.

Uit pastorale hoek het Jones (1979:95-107), vanuit die posisie en optrede van Moses in die Ou Testament, riglyne ontwerp om die pastorale bedoeling van Hebreërs beter te verstaan. Croy (1998) benader die opdrag tot volharding in lyding soos dit voorkom in die Hebreërs, terwyl DeSilva (2000:56) Hebreërs vanuit die oogpunt van volharding in dankbaarheid ontgin. Lindars (1989:392) gaan selfs verder as hy nie net van bepaalde temas nie, maar van Hebreërs in die geheel sê: "The whole composition is paranesis, and the doctrinal exposition is subordinate to this purpose."

Afgesien van die motivering uit vakliteratuur oor Hebreërs, bied Hebreërs self ook interne getuienis van pastorale elemente. Dit word byvoorbeeld in Hebreërs 13:22 gestel: "Broeders, dit is my dringende versoek: Julle moet geduldig luister na hierdie woorde waarmee ek julle bemoedig het, al het ek dit net kortliks aan julle geskrywe." Die Hebreërskrywer bestempel self die boek as 'n logou tes parakleseos.

\section{Die breë struktuur van Hebreërs}

Breë buitelyne van die struktuur van Hebreërs is nodig om die wyer en nadere konteks van pastorale elemente te omlyn.

Coetzee (1986:8-9) bied die volgende gedagtestruktuur van Hebreërs met ' $n$ aanduiding van parakletiese elemente: 
Tema:

Ons het reeds in Christus die heerliker dinge beërf - volhard dan nou soos dit erfgename van die beloofde, volmaakte erfdeel betaam.

1. Hoofstuk 1:1-4: Preekfondament as inleiding

2. Hoofstuk 1:5-2:18: Wat ons in Christus beërf het as waarborg - Explicatio

3. Hoofstuk 3:1-16: Jesus: Seun oor God se huis - heerliker as Moses

4. Hoofstuk 3:12-15: Paraklese: Hou vrymoedigheid en hoop tot die einde toe vas

5. Hoofstuk 3:17-4:13: Jesus groter as Josua

6. Hoofstuk 4:1-11: Paraklese: Beywer julle om in te gaan

7. Hoofstuk 4:14-16: Jesus die volmaakte Hoëpriester

8. Hoofstuk 4:14: Paraklese: Laat ons die belydenis vashou ...

9. Hoofstuk 5:1-10: Jesus groter as Aäron

10. Hoofstuk 5:11-6:3: Paraklese: Groei tot volwassenes in die geloof

11. Hoofstuk 7:1-28: Jesus, die Middelaar van 'n beter verbond

12. Hoofstuk 8:1-10:18: Jesus, die Hoëpriester, bring 'n beter, volmaakte, eenmalige offer

13. Hoofstuk 10:19-13:19: Die groot paraklese: hierdie paraklese word versprei oor twee groter gedeeltes, naamlik 10:19-12:29, met as tema volharding, en 13:1-19, met as tema bemoediging tot 'n praktiese Christelike lewenswandel as 'n lofoffer aan God

14. Hoofstuk 13:20-21: Preekslot: Die preek was 'n logos tes parakleseos

15. Hoofstuk 13:22-25: Briefslot

Wat uit hierdie ontleding na vore kom, is dat pastorale elemente binne die vermanend-bemoedigende gedeeltes in Hebreërs verspreid 
voorkom - telkens na breëre uiteensettings van aspekte van God se genadewerk in Christus, ons groot Hoëpriester.

Die struktuuraanduiding van Guthrie (1996:117; vgl. ook Jang, 2007:66-70) toon breedweg 'n ooreenkoms met dié van Coetzee (1986). Guthrie neem Hebreërs 1:1-4 as inleiding tot die preek, met as tema: God het tot ons gespreek in die Seun. As verdere indeling neem hy Hebreërs 1:5-2:18 (die posisie van die Seun in verhouding tot die engele), en Hebreërs 4:14-10:25 (die posisie van die Seun, ons Hoëpriester, in verhouding tot die aardse offerdiens). Guthrie toon nie binne sy breë struktuur van Hebreërs die oorgange tussen die uitleg en die vermanend-bemoedigende paraklese aan nie, maar stel wel dat die "primary function of the hortatory material is emotional rather than educational" (Guthrie, 1996:139; vgl. Jang, 2007: $69)$.

\section{Verkondigingsbegrippe in Hebreërs}

Uiteraard kom verskeie verkondigingsbegrippe in Hebreërs voor. Enkele van hierdie begrippe word hieronder aangedui, terwyl breër op die begrip parakalein ingegaan sal word. Parakalein is 'n sentrale begrip in die Nuwe Testament vir herderlike bediening.

\subsection{Die begrip /aleo}

Hierdie begrip kom in Hebreërs 2:2 en 2:3 voor, asook in hoofstukke $5,6,9,12: 25$ en 13:7. Dit dui gewoonweg op praat, selfs informeel gesels (Louw \& Nida, 1989:397). Bogenoemde betekenis van die begrip kom veral na vore in Hebreërs 2:2 en 3 as kontras tussen die woord wat deur engele gespreek word en die Woord wat deur God gespreek is.

\subsection{Die begrip euaggelidzomai}

Kruger en Venter (2002b:577) toon aan dat hierdie begrip op twee plekke in Hebreërs voorkom, naamlik in Hebreërs 4:2 en 4:6, en betrekking het op die oordra van goeie nuus. Louw en Nida (1989:410) plaas genoemde begrip in die subdomein van "inligting aankondig". In hierdie opsig stem euagelidzomai grootliks ooreen met die betekenismoontlikheid van die verkondigingsbegrip kerussein wat veral betrekking het op die aankondiging van 'n nuwe stand van sake wat aangebreek het (vgl. Ellingworth, 1993:240-241). In Hebreërs 4:1-2 word die uitdrukking gebruik in die sin van goeie nuus wat reeds vir 'n lang tyd aan die gelowiges verkondig is. Hulle was dus blootgestel aan en bekend met die evangelie (vgl. Hurst, 1990:106-107). Dit is 
veelseggend dat tot die blye boodskap wat die gelowiges reeds ontvang het, ook die belofte behoort (vgl. Heb. 4:1).

\subsection{Die begrip martureo}

Die begrip martureo word slegs in Hebreërs 10:15 gebruik en beteken letterlik om in 'n regsaak te getuig. So 'n persoon se getuienis het die betekenisnuanse van om op die toneel teenwoordig te wees; om persoonlik te sien en te hoor. Die absolute voorwaarde vir sodanige getuie is dat die waarheid gepraat moet word. Flanigan (1997:207) stel dat die Heilige Gees se werk sterk na vore kom in hierdie verkondigingsbegrip. Wat die prediker verkondig, word deur die Heilige Gees in mense se harte betuig.

\subsection{Die begrip parakaleo}

Dit is reeds genoem dat die begrip parakaleo een van die mees sentrale begrippe in die Nuwe Testament is om pastorale sorg aan te dui, maar dan in die betekenismoontlikhede van vermaan of ' $n$ beroep doen op, en ook om te bemoedig en te vertroos (vgl. Pieterse, 1985:9; Venter, 2009:141). Louw en Nida (1989:185) plaas hierdie begrip binne die subdomein van "met diepe erns vra of versoek of pleit by iemand". Venter (2009:141) beredeneer dat die begrip parakalein in die Nuwe Testament 'n meervoudige gebruiksveld het, naamlik om te versoek in 'n gesindheid van smeking (Mark. 7:32); om iemand aan te spreek in 'n gesindheid van vermaning (Rom. 12:1); om hulp te bied in 'n gesindheid van vertroosting (2 Kor. 7:6); of om deur mense vertroos te word as 'n daad van die kant van God (2 Kor. 1:3).

Die pastorale begrip parakalein kom vyf keer in die Hebreërspreek voor en word vervolgens kortliks nader verken.

- In Hebreërs 3:13 word die gelowiges opgeroep om mekaar te bemoedig en te vertroos (Kruger \& Venter, 2002b:576). Die gemeente word hier aan God se roepstem wat tot die gelowiges kom, verbind.

- In Hebreërs 6:18 word parakaleo gebruik om God se bemoediging vir die gemeente aan te dui. Die prediker spoor die gelowiges aan om vas te hou aan die hoop wat hulle reeds het.

- Die gebruik van parakaleo in Hebreërs 12:5 dui op vermaning vanuit die Skrif om altyd te let op wat God in sy Woord aan die gelowiges voorhou. 
- Ook in Hebreërs 13:19 word parakalein as vermaning gebruik in die sin dat die gelowiges opgeroep word om vir hulle voorgangers te bid.

- Laastens word die begrip paraklesis in Hebreërs 13:22 gebruik om die doel van die Hebreërspreek te omskryf - dit was 'n preek van bemoediging (logos tes parakleseos).

\section{Perspektiewe op die reiniging van sonde deur die groot Hoëpriester as fundering van herderlike werk}

Dit is opvallend dat die uitdrukking reiniging vir die eerste keer, en ook meermale in Hebreërs voorkom. Reeds in Hebreërs 1:1-4 word van reiniging gepraat in die sin van versoening: "Nadat Hy die reiniging van ons sonde bewerkstellig het, het Hy gaan sit aan die regterhand van die troon van die Majesteit in die hoë hemel" (Heb. 1:3). Bauer (1979:387) stel dat die Griekse begrip vir reiniging, katharismos, veral vier gebruiksvelde in die Nuwe Testament en in ander klassieke literatuur het, naamlik om te reinig van liggaamlike onreinheid, die gesondmaak van siektes, die skoonmaak van kos en die reiniging van sonde. Hierdie laaste betekenis van die woord word in Hebreërs 1:3 gebruik. Dit is opvallend dat hierdie aksie van reiniging van sonde ook geparafraseer kan word met die volgende woorde: "He [Christ] is the one who died to cleanse us and clear our record of all sin ..." (Living Bible, 1974:1160).

In Hebreërs is dit ook duidelik dat die gedagte van reiniging of versoening nie net deur die begrip katharismos verwoord word nie, maar ook deur ander uitdrukkings. In Hebreërs 9:12 word gestel dat $\mathrm{Hy}$ "met sy eie bloed ... net een maal die heiligdom binnegegaan en 'n ewige verlossing tot stand gebring" het. En in vers 27 word geskryf: "Hy het net een keer ... verskyn om deur sy offer die sonde weg te neem". In Hebreërs 7:27 word gemeld dat "Hy ... immers vir eens en vir altyd 'n offer vir die sondes gebring [het] toe Hy Homself geoffer het".

Die gedagte van reiniging, versoening en offerande word verder in Hebreërs sterk verbind aan Jesus die groot Hoëpriester. In Hebreërs 2:17 - asook in die hele Skrif - word van Christus vir die eerste keer gestel: “... sodat Hy 'n barmhartige en getroue Hoëpriester voor God kon wees". Vir die doeleindes van hierdie artikel - pastorale elemente in die Hebreërspreek - is dit nodig om ook te kyk na die spesifieke pastorale of herderlike vereistes wat vir hierdie groot Hoëpriester geld. Hy moes nie iemand wees wat geen medelye (sumpathein) met ons swakhede kon hê nie (Heb. 4:15). Verder geld 
die vereiste dat sodanige Hoëpriester wel meegevoel (metriopathein) met ons swakhede kan hê (Heb. 5:2). (Op hierdie twee vereistes word onder 5 in meer besonderhede ingegaan.)

Vanuit 'n pastorale hoek is dit egter ook van belang om te let op die beweging, of verdere voortgang in die gebruik van die naam groot Hoëpriester in Hebreërs. Hierbo is reeds daarop gewys dat die benaming vir Christus, naamlik die groot Hoëpriester, die eerste keer in die hele Skrif voorkom in Hebreërs 2:17. So begin Hebreërs. Hoe eindig Hebreërs? Die benaming groot Hoëpriester aan die begin van Hebreërs loop deur op die naam Leidsman en Voleinder van ons geloof in Hebreërs 12:1-2, en loop aan die einde van Hebreërs uit op die naam groot Herder van sy kudde (Heb. 13:29). Die benaming, groot Herder, vind ook weerklank in die derde laaste vers van Hebreërs waar die skrywer sy doel met die skryf van die brief aan die Hebreërs formuleer. Die doel was naamlik 'n logos tes parakleseos - 'n (herderlike) woord van bemoediging.

\section{Perspektiewe op medelye en empatie in die werk van die groot Hoëpriester}

Hebreërs vestig nie net die aandag daarop dat die groot Hoëpriester se werk daarop uitloop dat Hy die groot Herder is nie, maar ook op die wyse waarop Christus, die groot Hoëpriester, sy priesterlike werk verrig het. Hiervoor is ' $n$ nadere verkenning van twee begrippe nodig:

In Hebreërs 4:15 word gestel: "Die Hoëpriester wat ons het, is nie een wat geen medelye (sumpathein) met ons swakhede kan hê nie ..." In Hebreërs 5:2 word gestel: "Hy kan meegevoel (metriopathein) hê met die onwetendes en dwalendes, omdat hyself aan swakheid onderhewig is." Dit gaan hier om die onderskeid tussen die twee begrippe sumpathein (4:15) en metriopathein (5:2). Hewitt (1975:93) betoog dat die begrip sumpathein meer as net blote simpatie met ander lydendes uitdruk. Wat veral tot uitdrukking kom, is die betekenisnuanse van: "He has suffered, but also that $\mathrm{He}$ suffers when His children suffer" (Hewitt, 1975:93-94). Hy ly as 't ware mee met die swakhede van die een wat beproef of versoek word. Die ander uitdrukking, metriopathein, bring 'n verdere pastorale dimensie na vore. Die uitdrukking, metriopathein, is in die filosofie van Aristoteles gebruik in die betekenis van beheersing van iemand se gevoelens of passie om twee uiterstes te vermy, naamlik uiterste entoesiasme of uiterste lydelikheid. Die uitdrukking metriopathein word hier gebruik om aan te dui dat 'n aardse hoëpriester 
nie maar oor die sonde van mense mag heenkyk en onbewoë daaroor bly nie, maar hy mag ook nie so betrokke raak in sy meegevoel en passie vir die sondaar dat hy nie 'n "controlled feeling of sympathy" kan handhaaf nie (Rienecker, 1980:332; vgl. Thesnaar, 2009:160). Pastoraal gesproke omvat die begrip metriopathein die handhawing van die balans tussen afstand en nabyheid in die herderlike bediening en kan die implisiete betekenis daarvan aangedui word as empatie.

\section{Perspektiewe op 'n pastorale verhouding}

'n Herder van Christus se kudde is normaalweg betrokke in veelvuldige verhoudings, naamlik met God, met die gemeente en met die breëre gemeenskap. Die kwaliteit van 'n pastor se dienswerk hang grootliks af van die persoonlike en pastorale verhouding teenoor diegene wat hy/sy met die Woord bedien (Kim \& Venter, 1998:173).

In Hebreërs kom die gedagte van 'n pastorale verhouding na vore in die gemeenskapsgedagte soos veral verwoord in Hebreërs 3:1-19 en 10:19-25. Albei gedeeltes is vermanend-bemoedigende dele in Hebreërs. In Hebreërs 3:1 word die hoorders vir die eerste keer aangespreek as "heilige broeders" en in Hebreërs 10:19 word die aanspreekvorm "broeders" gebruik. Die gebruik van hierdie aanspreekvorms wat telkens na vore kom, dui op die gemeenskapsgedagte, die pastorale verhouding wat vooropstaan (vgl. Kruger \& Venter, 2002b:580). Al is dit so dat die skrywer van Hebreërs sy hoorders skerp vermaan, bly hulle "heilige broeders", medegelowiges in Chistus (vgl. Kistemaker, 1984:83; Guthrie, 1996:211). Die benaming "broeders" is 'n aanduiding dat die prediker hom één voel met die gemeente vanweë die feit dat vrye toegang tot God ook 'n nuwe onderlinge verhouding skep en veronderstel. Met só 'n herder kan die gemeente ook identifiseer (Venter, 2005:227). Die geloofsgemeenskap en pastorale verhouding word daarin begrond dat een en dieselfde Hoëpriester sy huis (gemeente) toerus en regeer en ook dat die gemeenskaplike belydenis van Christus se hoëpriesterskap die huisgenote van God se gesin saambind.

In die aanspreekvorm geliefdes in Hebreërs 6:9, is 'n verdere nuansering van die pastorale verhouding. Die skrywer het in die voorafgaande hoofstukke sy hoorders skerp vermaan. In die aanspreekvorm geliefdes gaan hy daartoe oor om teer woorde te gebruik woorde wat spreek van 'n geloofsverhouding in liefde (vgl. Kruger \& Venter, 2002b:581). In die uitdrukking "geliefdes" kom pastorale besorgdheid na vore (vgl. Hume, 1997:52). Die herder is besorg oor 
die gemeente en wil hulle nie tot moedeloosheid dryf nie. Hy wil hulle pastoraal begelei. Juis om hierdie rede wil hy ook die hoorders oortuig dat hy van beter dinge aangaande hulle oortuig is.

Hierdie aanspreekvorms in Hebreërs wat pastorale verhouding uitdruk, toon ooreenkoms met Paulus se aanspreekvorms vir Timoteus en Titus in die pastorale briewe. Hy spreek Timoteus aan as "my eie kind in die geloof" (1 Tim. 1:2) en in 1 Timoteus 1:18 noem Paulus hom "Timoteus my kind". In 2 Timoteus 1:2 word Timoteus "my geliefde seun" genoem, terwyl Titus in Titus 1:4 aangespreek word as "my eie kind in die geloof wat ons albei bely". Hierdie aanspreekvorms aan die begin van die pastorale briewe dui nie net op 'n diep pastorale verhouding tussen Paulus en Titus nie (vgl. Stott, 1997: 40), maar ook die feit dat die aanspreekvorm in die briewe self herhaal word, dui daarop dat die pastorale verhouding deurgaans funksioneer.

\section{Pastorale perspektiewe vanuit die begrip bedienaar}

Een van die begrippe wat in Hebreërs vir dienaar gebruik word, toon 'n besondere pastorale inhoud. In die pastorale briewe word die uitdrukking diakonos feitlik deurgaans vir dienaar gebruik. In Hebreërs 3:5 word die meer algemene uitdrukkings, naamlik diakonos, oiketes of doulos nie gebruik nie (Hewitt, 1975:79), maar wel therapon om Moses as dienaar in die huis van God aan te dui. "The word suggests a personal service freely rendered. It denotes both the willing service rendered as well as the relationship between the one serving and the one he serves." (Rienecker, 1980:326.) Hebreërs 3:5 is 'n aanhaling uit Numeri 12:7 waar die Here van Moses sê: "Hy is die betroubaarste in my diens".

Die begrip therapon word slegs een maal in die Nuwe Testament gebruik om dienaar aan te dui, naamlik hier in Hebreërs 3:5. Louw en Nida (1989:460) plaas hierdie begrip binne die subdomein van "diens in die betekenis van bystand aanbied, sekere pligte uitvoer, of gewoon net om te help". So word die bereidwilligheid van die dienaar beklemtoon om so goed as moontlik te dien (vgl. De Klerk \& De Wet, 2008:62-84; Pieterse, 2009:10-11). Die daad van pastoraal teenwoordig wees, kom in hierdie uitdrukking na vore. Die begrip het verder ook die konnotasie van genesing en herstel. Uit die konteks van Hebreërs 3:5 is dit duidelik dat therapeuein veral dienslewering in die huis(gesin) en huishouding van God inhou ten einde 'n gesonde stand van sake te bevorder. Kruger en Venter (2002a:352) beklemtoon dat die begrip therapon ook 'n tekenkarakter het, omdat dit die aandag vestig op die (herstellende) dienswerk wat Christus 
gedoen het. Herderlike werk het dus 'n terapeutiese funksie, omdat dit die herstel (genesing) van die verhouding met God ten doel het (vgl. Fourie, 2008:178).

\section{Pastorale perspektiewe op gelowiges as herders vir mekaar}

Die gedagte dat gelowiges in onderlinge verbondenheid met mekaar lewe, kom besonder sterk in die Nuwe Testament na vore. Veral in die Evangelie van Johannes word nie slegs die innige verbondenheid van Christus en sy dissipels beklemtoon nie (bv. in Joh. 15:5: "Bly in My en Ek in julle"), maar ook die onderlinge verbondenheid met mekaar in uitdrukkings soos: "Julle moet mekaar liefhê" (Joh. $6: 17)$. In Efesiërs en ander briewe van Paulus is die uitdrukking in Christus ' $n$ aanduiding van gelowiges wat met mekaar verbind is omdat hulle in verbondenheid met Christus lewe. Die gedagte van verbondenheid aan en sorg vir mekaar is ook in bepaalde metafore vervat wat in die Nuwe Testament vir die kerk gebruik word. Miskien is die metafoor van Christus as liggaam en die gelowiges as ledemate die sprekendste in die betekenis van hulp aan en sorg vir mekaar. Die ondersteuning van mekaar kom ook na vore in die metafore van tempel en gebou.

Dat gelowiges as herders vir mekaar geroep word, word in Hebreërs 10:24-25 gestel. Hierdie verse word voorafgegaan deur die stelling in vers 19 dat gelowiges nou vrye toegang het tot die heiligdom. Die hoëpriester in die Ou Testament het slegs een keer per jaar toegang tot die binneste van die heiligdom gehad, nadat hy eers vir sy eie sondes geoffer en homself gereinig het met die bloed van 'n offerdier. In die lig van die werk van die groot Hoëpriester, "... het ons vrye toegang tot die heiligdom ...". Bauer (1979:631) stel dat die woord wat hier vir vrye toegang gebruik word (parresia) die konnotasie het van die reg om jouself openlik, vreesloos en in volle vryheid uit te druk. Onlosmaaklik verbind aan hierdie reg tot vryheid, is ook die verbondenheid van gelowiges aan mekaar. So kom die opdrag tot gelowiges in Hebreërs 10:24: "Laat ons ook na mekaar omsien ...", dit wil sê om as 't ware geestelike oë op mekaar te rig en gerig te bly hou. Hoe geskied hierdie omsien na mekaar? "Deur mekaar aan te spoor tot liefde en goeie dade." "Aanspoor" kan hier goedskiks vertaal word met "opskerp". Die punt van belang is dat gelowiges nie soos klippe individueel en los van mekaar lewe nie, maar op mekaar aangewese is (vgl. Louw, 2009:128). Die uitdrukking goeie dade hou in dat gelowiges mekaar ook tot slegte dade 
kan aanspoor. Moontlik was dit die situasie met die Hebreërs in daardie tyd.

Die volgende perspektief op gelowiges as herders vir mekaar kom na vore in die bevel om nie van die onderlinge byeenkomste af weg te bly nie. Die onderliggende betekenis van "wegbly" is om in die steek te laat. Gelowiges wat van die onderlinge byeenkomste van die gemeente af wegbly, laat mekaar in die steek. Bloot deur hulle teenwoordigheid by die onderlinge byeenkomste versterk gelowiges mekaar alreeds. Juis daarom volg die opdrag om “... mekaar eerder aan [te] moedig (parakalountes) om daarheen te gaan". Op hierdie wyse is gelowiges herders vir mekaar.

\section{Pastorale perspektiewe op spiritualiteit}

Onder spiritualiteit word hier die persoonlike verhouding van 'n gelowige met God verstaan. Spiritualiteit sluit aspekte in soos 'n lewe in toewyding aan God, 'n voortdurende beoefening van en toerusting vir groei en 'n verdiepte verhouding met God. Prakties omvat spiritualiteit hier aspekte soos Skrifstudie, Skrifbepeinsing en gebed en 'n konkrete lewe in heiligmaking.

In Hebreërs kom verskeie aspekte van spiritualiteit na vore:

\section{- $\quad$ Spiritualiteit as die gebruik van voedsel wat geestelik laat groei}

In Hebreers 5:11 word van die gemeente gestel dat hulle "traag geword het om te leer" en in vers 12 word vervolg dat "hulle teen hierdie tyd self onderrig behoort te gee". Hulle is al so lank gelowiges, maar is nog nie geloofsvolwasse nie; daarom moet hulle weer opnuut in die grondwaarhede van die Woord van God onderrig word. Met hierdie woorde gryp die skrywer terug op die ernstige vermaning in Hebreërs 2:1: "Om hierdie rede moet ons soveel kragtiger vasgryp aan wat ons gehoor het, sodat ons nie dalk wegdrywe nie". Hierna volg die veelseggende uitspraak in Hebreërs 5:11: "'n Mens moet julle met melk voed en nie met vaste kos nie" (v. 12). In hulle beoefening van spiritualiteit het iets ernstigs ontbreek: voeding uit die Woord. Die Hebreërs het nie verder gegroei as suigelinge nie en het daarom nie insig in die Woord ontwikkel nie. "If the dark things do not become plain, then the plain things will become dark." (Hewitt, 1975:101.) Die voeding vir hulle spiritualiteit het slegs uit melk bestaan - uit ' $n$ kind se kos. Dit is juis om hierdie rede dat die gemeente nie die vermoë gehad het om te kon onderskei tussen reg 
en verkeerd nie - destyds moontlik tussen Judaïstiese en Christelike leerstellings.

Die remedie vir die gebrek aan onderskeidingsvermoë, die vlak van "melkkos-gelowiges", is om "vaste-kos-gelowiges" te word, want "[v]aste kos is vir grootmense, vir mense wat oor insig beskik en wat deur ervaring geoefen is om tussen goed en kwaad te onderskei" (v. 14). Die begrip wat hier vir ervaring gebruik word, heksis, het die betekenismoontlikhede van gewoonte of reëlmaat. "It refers to a habit of body or mind indicating not the process but the result; i.e., the condition has been produced by past exercise and is then the habitual or normal condition, the disposition or character." (Rienecker, 1980:334.) Groei in spiritualiteit verdiep net deur vaste voedsel in te neem en sodoende in geloofsvolwassenheid toe te neem.

\section{- $\quad$ Spiritualiteit en 'n opregte hart}

Op Hebreërs 10:19-25 is reeds in afdeling 8 gefokus in die behandeling van die perspektief dat gelowiges herders vir mekaar is. Hebreërs 10:21 en 22 hou ook verband met die spiritualiteit van gelowiges. In vers 21 is weer ' $n$ teruggryping op die deurlopende tema in Hebreërs, naamlik die groot Hoëpriester wat ook Priester oor die huis van God is. Juis omdat Hy ook die groot Priester oor die huis van God is, volg die konsekwensie daarvan in vers 22: "Laat ons tot God nader met 'n opregte hart en met volle geloofsekerheid". Die gebruik van enkelvoud en meervoud in vers 22 val op: Laat ons (meervoud) nader met ' $n$ opregte hart (enkelvoud). Die implikasie is dat ons as gelowiges saam na God kan gaan, maar voor God moet elkeen individueel verskyn met 'n opregte hart. In ons gaan na God kan ons mekaar se hande vat, maar voor God staan ons individueel en die toets is of ons daar staan met 'n opregte (ware) hart. Die uitdrukking "opreg" het hier die betekenisnuanse van 'n opregte hart, in gees en in waarheid, sonder enige skyn of huigelagtigheid. Die begrip waar word ook in Hebreërs 8:2 gebruik waar Christus aangedui word as die "ware verbondstent" as aanduiding van die teenstelling tussen aardse en hemelse verbondstent (die teenwoordigheid van Christus).

\section{Pastorale perspektiewe op die moontlike sin van lyde}

Die vraagstuk van die sin van lyde word wyd in pastorale literatuur behandel en beskryf. Kernvrae rondom lyding is: Wíl God lyding? Waarom moet skynbaar onskuldige mense, byvoorbeeld kinders, ly? Waarom ly regverdiges, maar goddeloses floreer? Kan of wil God nie lyding voorkom nie? Ook in vakliteratuur oor Hebreërs is op wyer 
vlak oor die vraagstuk van lyding besin. Young (2003:47-59) maak 'n saak daarvoor uit dat lyding 'n sleutel is om Hebreërs te verstaan. Moessner (2003:280-290) interpreteer lyding as 'n stap op die weg van heiligmaking. Die navorsing van Eisenbaum (1999:331-353) het dieselfde aksent.

In hierdie onderafdeling word veral aandag gegee aan die ontginning van enkele gedeeltes uit Hebreërs met die oog op sinduiding in lydensituasies, dit wil sê met die aanduiding vanuit die Skrif van 'n moontlike singewing in 'n lydensituasie.

Op meer plekke in die Nuwe Testament is daar sprake van sinduiding. Hierdie stelling word soos volg toegelig:

- In Filippense 1:12-13 stel Paulus:

Ek wil hê dat julle moet weet broers dat wat my oorgekom het, juis die verkondiging van die evangelie bevorder het. Dit het daarop uitgeloop dat die hele keiserlike wag en al die ander nou besef dat dit ter wille van Christus is dat ek 'n gevangene is.

'n Moontlike sin van Paulus se lyding in die gevangenis is dat die evangelie aan die keiserlike wag verkondig is en dat hulle tot geloof gekom het. Sy lyding bevorder dus die verspreiding van die evangelie.

- In 1 Petrus 4:1 word 'n ander moontlike singewing aan lyde gegee:

Omdat Christus liggaamlik gely het, moet julle julle ook met die gedagte wapen dat wie liggaamlik gely het, met die sonde afgereken het: vir die res van sy aardse bestaan word sy lewe nie meer beheers deur menslike begeertes nie, maar deur die wil van God.

In hierdie gedeelte kom as moontlike singewing van lyding eerstens na vore dat, omdat Christus liggaamlik gely het, sy volgelinge ook sal ly, nie om vir hulle skuld te betaal nie, maar omdat hulle Christus navolg. ' $\mathrm{n}$ Tweede moontlike singewing is ook dat wie liggaamlik gely het, met die sonde afgereken het, dit wil sê nie meer in die posisie of gewoonte is om altyd te sondig nie. Wie liggaamlik ly, word ook van geleenthede ontneem om prakties in die sonde te val, hoewel so 'n persoon nog in sy gedagte en woorde kan sondig.

Die vraag is nou of daar in Hebreërs ook sprake is van sinduiding? Enkele gedeeltes word nou verken. 
- In Hebreërs 10:33 word gestel: "Deels is julle deur beledigings en vervolging openlik tot bespotting gemaak en deels het julle gely omdat julle julle vereenselwig het met ander wat hierdie dinge oorgekom het." Die moontlike sin van lyding in hierdie gedeelte kan weergegee word as lyding as gevolg van of ter wille van koinonia. Eenvoudig gestel: Indien die gelowiges nie in die lot van lydende medegelowiges gedeel het nie, sou hulle self nie gely het nie. Lyding kan dus ook die verbondenheid met medegelowiges in hulle swaarkry as sin hê.

- 'n Soortgelyke gedagte kom ook in Hebreërs 10:34 na vore:

Julle het met die gevangenes meegevoel gehad (sunepathesate; letterlik saam met hulle gely), en toe op julle besittings beslag gelê is, het julle dit met blymoedigheid aanvaar omdat julle geweet het dat julle ' $n$ besitting het wat beter en blywend is.

Hoe swaar ook al om besittings te verloor, het dit by die Hebreërs die oortuiging versterk en bevestig dat daar 'n beter en blywender besitting is as hierdie aardse besittings. So het hulle swaarkry, deur deelgenootskap aan ander se swaarkry en verlies van eie besittings, die sin en bewustheid van hulle swaarkry as voorloper van 'n beter toekoms, skerper in die visier gestel.

- Hebreërs bied ook 'n perspektief op die sin van Christus se lyding. In Hoofstuk 12:1-3 word gehandel oor Jesus as die Begin en Voleinder van die geloof. Op Hom moet die oog van die gelowiges gevestig wees om te kan volhard in die wedloop van die geloof. Hy het die wedloop voltooi. Christus is nie net die voorwerp van ons geloof nie. Hy is ook die voorbeeld vir ons geloof. Hierna volg die veelseggende uitspraak in vers 2: "Ter wille van die vreugde wat vir Hom in die vooruitsig was, het Hy die kruis verduur sonder om vir die skande daarvan terug te deins en Hy sit nou aan die regterkant van die troon van God." Die lyding van Christus was nie net die betaling vir ons skuld nie. Daarin was ook die singewing van vreugde vervat, wat ná die betaling van die skuld wag. Vers 2 sluit dus af met die woorde dat Hy nou (in vreugde) aan die regterkant van die troon van God sit.

Hoewel lyding nooit verheerlik mag word nie, kan die sin daarvan nou reeds, nog vóór die lyding afgehandel is, die voorsmaak wees van die vreugde wat wag.

- Laastens word aandag gewy aan die bekende uitspraak in Hebreërs 12:7: "Verdra die tug as opvoeding, want God behandel 
julle as sy kinders. Is daar miskien 'n kind wat nie deur sy vader getug word nie?" Hierdie vers word in vers 6 voorafgegaan deur die uitspraak dat die Here dié tug wat hy liefhet. Wat hier in die visier kom, is dat tug swaarkry en selfs lyding, soms opvoeding as bepaalde singewing mag hê. Lyding wat oor mense kom, kom nie in toorn nie, maar in God se liefde. Die metafoor van 'n aardse vader word hier juis gebruik om aan te dui dat dit nie 'n harde tiran is wat willekeurig straf uitdeel nie. Juis om hierdie rede word in vers 10 vervolg: "... maar Hy tug ons tot ons beswil sodat ons in sy heiligheid mag deel". Tug is dus tot voordeel, met die oog op die beste vir 'n kind. Hierdie tug stel ook in staat om vryer te wees van die mag van die sonde en sodoende deelgenote van God se heiligheid te wees.

Aan die einde van die bestudering van die enkele moontlike singewings van lyding in Hebreërs moet beklemtoon word dat lyding nie net 'n enkele singewing (bv. opvoeding) het nie. In die pastorale handeling van sinduiding moet dit ook nie eenduidig gehanteer word nie. Die mees pastoraal verantwoorde opsie bly om aan iemand verskillende moontlikhede uit die Skrif voor te hou van wat die sin van lyding mag wees en dit aan hom/haar te laat om gaandeweg self God se stem op die sinvraag in die eie lyding te hoor en op die spesifieke eie lydensituasie toe te pas.

\section{Pastorale perspektiewe op hoop vir môre en volharding vir vandag}

Die gedeelte in die Hebreërspreek wat hier ondersoek word, is Hebreërs 11:1 en Hebreërs 12:1-2.

In Hebreërs 11:1 word as 't ware 'n definisie van geloof vanuit die direkte konteks van hoofstuk 10 gebied. Die slotwoorde in hoofstuk 10:39 is: "... nee, ons glo en ons sal lewe". Juis om hierdie rede gaan die outeur van Hebreërs direk daartoe oor om in Hebreërs 11:1 geloof te definieer, met ander woorde om direk die essensie van geloof weer te gee. Vir die doeleindes van hierdie artikel is die uitdrukking in 11:1 veral van belang: "Om te glo is om seker te wees van die dinge wat ons hoop ...". Letterlik vertaal staan hier: Die geloof is die versekering van hopendes. Die "is" staan heel voor in die sin om aan hierdie gedeelte as 't ware die klem van 'n definisie van geloof te gee. Die betekenismoontlikhede van die woorde "om seker te wees", of "versekering", is die weergawe van die Griekse begrip hupostasis wat 'n wye betekenisveld in die Nuwe Testament het, naamlik die wese van Jesus, soos dit in Hebreërs 13 gestel word: "Hy is die ewebeeld van die wese van God". Verdere bete- 
kenisnuanserings van hupostasis sluit in: waarborg en vertroulike versekering. Besonder konkreet en sprekend kan die uitdrukking hupostasis ook weergegee word as regsdokumente wat die bewys van eienaarskap bevat (vgl. Rienecker, 1980:360). Geloof is met ander woorde vandag die titelakte, of die kaart en transport van die dinge waarop gelowiges hoop vir môre (vgl. Hewitt, 1975:171). Juis hierom word geloof, hoop en volharding so dikwels as 't ware in kombinasie in Hebreërs gebruik. Die konkrete bewys van die uiteinde van die geloof is die krag vir hulle van wie in Hebreërs 11 getuig word.

Die tweede aspek wat in hierdie onderafdeling na vore kom, is die oproep tot volharding soos dit in Hebreërs voorkom (vgl. Kim, 1997:280-290; Van der Merwe, 2005:329-354).

Hebreërs 11 word met hoofstuk 12 verbind deur 'n sterk oorgangskakel: "Daarom dan [of: "terwyl ons dan] so 'n groot skare van geloofshelde om ons het ... laat ons die wedloop wat vir ons voorlê met volharding hardloop." Die definisie van geloof in hoofstuk 11:1 het die versekering vir die toekoms in die oog. Die oproep tot volharding in Hebreërs 12:1 het die geloofsaksie in die hede in die oog. Volharding (hupomone) het hier die konnotasie van geduldige uithou of verduur om die wil van God te kan doen. In Hebreërs 10:36 word aan die gemeente gestel: "Volharding is wat julle nodig het om die wil van God te doen en te ontvang wat Hy beloof het." Miskien is die sprekendste uitdrukking in verband met die begrip volharding dat in Hebreërs 12:2 die volgende van Jesus gestel word: "Ter wille van die vreugde wat vir Hom in die vooruitsig was, het Hy die kruis verduur (hupemeinen) sonder om vir die skande daarvan terug te deins ...". Vir die gelowige se volharding en vir Christus se verduur word dieselfde uitdrukking in Hebreërs 12:1-2 gebruik.

\section{Samevattende stellings uit die pastorale ontginning van Hebreërs}

- Herderlike werk moet gefundeer word in die reinigingswerk van ons groot Hoëpriester wat vir eens en vir altyd ons sonde en sondeskuld weggeneem het. (Hierdie pastorale element kan herderlik bedien word aan gelowiges met ingrypende skuldgevoelens en diegene wat aan die beslissende daad van skuldvergiffenis twyfel.)

- Die reinigingswerk van die groot Hoëpriester word prakties gekonkretiseer in sy werk as Leidsman van ons geloof en mond uit in sy werk as die groot Herder van sy kudde. (Hierdie pastorale 
element kan onder andere toegepas word in die bedieningswyse van persone wat na skuldbelydenis diep berou ervaar.)

- Die gang, diepte en rigting van pastorale bediening word grootliks bepaal deur die pastorale verhouding waarin die herder met lidmate staan. (Die element van pastorale verhouding funksioneer omvattend in elke pastorale handeling en behoort sterk na vore te kom in die houding, aanslag en ingesteldheid van die pastor.)

- In herderlike werk moet simpatie nie empatie verdring nie. Empatie beteken dat die balans tussen afstand en nabyheid in herderlike bediening gehandhaaf word. Simpatie sonder empatie hou in dat meegevoel so eensydig kan wees dat herderlike begeleiding nie moontlik is nie. (In alle pastorale handelinge moet die balans tussen afstand en nabyheid gehandhaaf word. Indien die aspek van afstand oordryf word, word pastorale werk klinies en koud. Indien die aspek van nabyheid oordryf word, raak 'n pastor subjektief betrokke en kan hy/sy nie waarlik herder wees nie.)

- Herderlike werk in 'n gesindheid van diens het 'n helende aard. (Juis die oorgawe in diens hou in dat die pastor in sy bediening ' $n$ oorgang gemaak het van pastorale handeling na pastoraal teenwoordig wees - die oorgang van doing na being).

- Die grondvorm van pastorale bediening is dat die gemeente mekaar herderlik versorg. (Die gemeente behoort volgens sy eie aard en gawes toegerus te word vir 'n wye spektrum van herderlike werk aan ander medegelowiges, byvoorbeeld siekebesoek, die bystaan van diegene met alkoholverslaafdheid en ander middels, gesprekvoering met medelidmate in situasies van geldnood, armoede, huweliksonmin, ensovoorts.)

- In die spiritualiteit van bedienaar en gemeente moet die klem geplaas word op groei in geloofsvolwassenheid deur verdiepte omgang met die Woord, en ook op 'n opregte hart in die omgang met God. ('n Persoonlike verhouding met God en geloofsgroei op weg na geloofsvolwassenheid moet konkreet na vore kom in Bybelstudiegroepe, gebedsgroepe, bepeinsing en ook in verwondering oor wie God is en wat God doen.)

- Daar is meer as een singewing van lyding moontlik. 'n Sin van lyding kan wees om tot verdiepte koinonia in die gemeente te kom, en om tot 'n verdiepte bewuswording te kom van 'n erfdeel blywender as die aardse. (Hierdie aanduiding van moontlike sin kan toegepas word by die herderlike versorging van terminaalsiekes, 
by treurendes ná die dood van 'n naasbestaande, kanker- en vigs-lyers, bejaardes en mense in groot armoede.)

- Geloof kan vergelyk word met die eiendomsbewysreg van die erfdeel waarop gehoop word. Volharding in die hede is onlosmaaklik aan geloof verbonde. (Die pastorale elemente van hoop en volharding kan toegepas word in die herderlike versorging van sterwendes, twyfelaars en verslaafdes wat terugval in verslawing.)

Hebreërs blyk dus 'n ryke toepassingsveld vir die herderlike bediening te bied - ' $n$ veld wat deur pastors meer bewustelik ontgin behoort te word.

\section{Geraadpleegde bronne}

BAUER, W. 1979. A Greek-English lexicon of the New Testament and other early Christian literature. Trans. by W.F. Arndt \& F.W. Gingrich. Chicago: Chicago University Press.

BRITS, H.J. 2001. Die transformasiekrag van die metafoor in die geloofspraksis met spesiale verwysing na prediking. Pretoria: Universiteit van Suid-Afrika. (D.Th.-proefskrif.)

COETZEE, J.C. 1986. Analise van gedagtestruktuur van die Hebreërpreek. Potchefstroom: Potchefstroomse Teologiese Publikasies.

CROY, N.C. 1998. Endurance in suffering: Hebrews 12:1-13 in its rhetorical, theological and philosophical context. Cambridge: Cambridge University Press.

DE KLERK, B.J. \& DE WET, F.W. 2008. Preacher on the edge: exposure to vulnerability as a new opportunity in preaching the righteousness of the kingdom of God. Praktiese teologie in Suid-Afrika, 23(2):62-84.

DESILVA, D.A. 2000. Perseverance in gratitude: a socio-rhetorical commentary on the episte "to the Hebrews". Grand Rapids: Eerdmans.

DU PREEZ, A.P. \& VENTER, C.J.H. 2007. Gesindheid as kommunikasiesteurnis ("geruis") in die prediking: basisteoretiese perspektiewe vanuit die gelykenis van die saaier (Luk. 8:4-15). In die Skriflig, 41(2):233-257).

EISENBAUM, P.M. 1999. The virtue of suffering, the necessity of discipline and the pursuit of perfection in Hebrews. New York: Routledge.

ELLINGWORTH, P. 1993. Commentary on Hebrews. Grand Rapids: Eerdmans.

FLANIGAN, J.M. 1997. Hebrews: what the Bible teaches. Kilmarnock: John Ritchie.

FOURIE, J.H.v.S. 2008. "Medelye-moegheid": 'n pastorale benadering. Potchefstroom: NWU. (Ph.D.-proefskrif.)

GUTHRIE, D. 1996. Hebrews: Tyndale New Testament commentaries. Grand Rapids: Eerdmans.

HEWITT, T. 1975. Hebrews: Tyndale New Testament commentaries. Grand Rapids: Eerdmans.

HUME, C.R. 1997. Reading through Hebrews. Lymington: Spartan.

HURST, L.D. 1990. The epistle to the Hebrews: its background of thought. Cambridge: Cambridge University Press.

JANG, J.Y. 2007. Communicative preaching: a homiletical study in the light of Hebrews. Potchefstroom: NWU. (Ph.D. thesis.) 
JOHNSTON, G. 2001. Preaching to a postmodern world. Grand Rapids: Baker.

JONES, P.R. 1979. The figure of Moses as heuristic device for understanding the pastoral intent of Hebrews. Review \& expositor, 76(1):95-107.

KIM, D. 1997. Perseverance in Hebrews. Skrif en kerk, 18(2):280-290.

KIM, H.K. \& VENTER, C.J.H. 1998. Preacher and spirituality: perspectives from the Pastoral Epistles. In die Skriflig, 32(2):161-179.

KISTEMAKER, S.J. 1984. Hebrews: New Testament commentary. Grand Rapids: Baker.

KRUGER, F. 2004. Verandering in die kerk: maak seker jy verstaan dit. Middelburg: Kruger.

KRUGER, F.P. \& VENTER, C.J.H. 2002a. Die prediker as toeruster van die gemeente: basisteoretiese perspektiewe vanuit Hebreërs. In die Skriflig, 36(3):349-368.

KRUGER, F.P. \& VENTER, C.J.H. 2002b. Prediking en die gesindheid van die hoorders: basisteoretiese perspektiewe vanuit Hebreërs. In die Skriflig, 36(4):573-592.

KRUGER, F.P. \& VENTER, C.J.H. 2003. 'n Homileties-empiriese ondersoek van prediking en gesindheidsverandering. In die Skriflig, 37(3):461-484.

LINDARS, B. 1989. The rhetorical structure of Hebrews. New Testament studies, 35(3):382-406. (New International Greek Testament commentary.)

LIVING BIBLE. 1974. Wheaton: Tyndale House.

LOUW, D.J. 2009. Please quit your God! Intoxication in Christian spirituality and the healing dimension within an existential approach to a practical theological ecclesiology. (In Pieterse, H.J.C. \& Thesnaar, C.H. A faithful witness: essays in honour of Malan Nel. Wellington: Bible Media. p.125138.)

LOUW, J.P. \& NIDA, E.A. 1989. Greek English lexicon of the New Testament. Vol. 2. New York: United Bible Societies.

MOESSNER, J.S. 2003. The road to perfection: an interpretation of suffering in Hebrews. Interpretation, 57(3):280-290.

OPPERMAN, W.C. 1995. Die motief van vreemdelingskap en vaderland in Hebreërs: 'n eksegetiese studie met toespitsing op Hebreërs 11:8-22. Potchefstroom: PU vir CHO. (Ph.D.-proefskrif.)

PFITZNER, V.C. 1993. The rhetoric of Hebrews: paradigm for preaching. Lutheran theological journal, 27(5):3-12.

PIETERSE, H.J.C. 1985. Verwoording en prediking. Pretoria: NG Kerkboekhandel.

PIETERSE, H.J.C. 2001. Prediking in 'n tyd van armoede. Pretoria: Unisa.

PIETERSE, H.J.C. 2009. The theological approach of Malan Nel. (In Pieterse, H.J.C. \& Thesnaar, C.H. A faithful witness: essays in honour of Malan Nel. Wellington: Bible Media. p. 3-18.)

RIENECKER, F. 1980. A linguistic key to the Greek New Testament. Vol. 2. Grand Rapids: Zondervan.

STOTT, J.R.W. 1997. The message of Timothy and Titus. Leicester: InterVarsity.

THESNAAR, C.H. 2009. Showing compassion in crisis times: confronting alienated adolescence [sic] facing death. (In Pieterse, H.J.C. \& Thesnaar, C.H. A faithful witness: essays in honour of Malan Nel. Wellington: Bible Media. p.153-164.)

VAN DER MERWE, D.G. 2005. Perseverance through suffering. Missionalia, 33(2):329-354. 
VENTER, C.J.H. 2001. Verklarende prediking - 'n herevaluering. In die Skriflig, 35(4):513-536.

VENTER, C.J.H. 2005. Prediking wat transformeer: prakties-teologiese gesigspunte. In die Skriflig, 39(2):217-237.

VENTER, C.J.H. 2009. Pastor and social intelligence. (In Pieterse, H.J.C. \& Thesnaar, C.H. A faithful witness: essays in honour of Malan Nel. Wellington: Bible Media. p.141-151.)

YOUNG, N.H. 2003. Suffering: a key to the epistle to the Hebrews. Australian Biblical review, 51:47-59.

\section{Kernbegrippe:}

geloof (betekenismoontlikheid in Hebreërs)

Hebreërs

Hoëpriester, Groot

lyding, sinduiding van

spiritualiteit

volharding

\section{Key concepts:}

faith (meaning of in Hebrews)

Hebrews

Highpriest, Great

perseverance

spirituality

suffering, meaning of 
